\title{
MIKLÓS WESSELÉNYI AND NATIONALITY ISSUES IN 1830-1849 HUNGARY
}

\author{
JAMES WILDE \\ Indiana University, Bloomington, IND, \\ USA
}

\section{Introduction}

In April, 1806, nearly four hundred nobles met in a session of the Közép-Szolnok county assembly in Northern Transylvania. The speaker before them came from a prestigious family whose ancestors had addressed that body for two centuries. None of this was unusual. What was extraordinary was that the speaker was nine years old. In his youthful voice, he announced to them his intention to become a patriot:

Fathers and Patriots! ...

I already feel such a love for my country and to you. Fathers! I also want to be a patriot. You work with a noble fire. And why? So that you may bring us happiness.

Oh, fathers, please believe that my spirit is so ready to follow in your footsteps. But my nine-year-old body is my obstacle. I am not like Alexander the Great who envied his father's achievements. There is enough work for all of us to do. But what sort of work? We will raise the pillars skyward for you. And what you do not finish, we shall complete with your same noble fire ...

... Keep your eyes on me. And do not forget that today I have dedicated myself to become a patriot. In just a short time you will see that I have not disappointed your expectations of me. ${ }^{1}$

The lad was Miklós Wesselényi who, faithful to his promise, became a leader in the Hungarian Reform Movement from 1830 to 1849. At times his dreams for renascent Hungary seemed so bright with promise. But the patriot's path was also strewn with disappointments, treason trials, imprisonment, blindness and an early "civic death."

There was also the conflict between the nation's Magyars and its nationalities. Wesselényi saw the ethnic battle lines forming much earlier than did most Hungarians. He was partly a sage, partly a product of his time. In hindsight some of his proposals seem naïve today and a number of his ideas were ill-timed because of 
domestic or external political conditions. His analysis of a problem was sometimes sharper than his solution. But in a time of rising ethnic nationalism, he tried to find a common ground on which Magyars and non-Magyars could meet in order to avert what may have been an inescapable clash. He saw that unless the nationality divisions and conflicts were resolved, they would be exploited to weaken, or perhaps destroy, the Hungary he knew.

Wesselényi has not been ignored by historians of Reform Age Hungary, but his role has been overshadowed. His time of greatest political influence (1830-35) was wedged between the meteoric rise of his early friend, István Széchenyi, before him and the towering later figures of Lajos Kossuth in 1848-49 and Ferenc Deák in 1867-68. Wesselényi’s modern biographer, Zsolt Trócsányi, calls him the "Father of Hungarian Liberalism." 2 But more important than his title is the answer to the question: "Was Wesselényi so important to Hungary's Reform Age that the period cannot be truly understood without knowing of his role in it?" Were this question asked about Deák, Széchenyi or Kossuth, the answer would clearly be in the affirmative. A case can be made that Wesselényi also should belong to that select group.

One Wesselényi biographer divides his public life into two periods, one basically encompassing the 1830 years, the other the 1840s. During the first, Wesselényi drafted his reform program, much of which is found in Balitéletekröl (About Prejudices). In the second, he addressed nationality issues in his Szózat a magyar és szláv nemzetiség ügyében (An Appeal in the Hungarian and Slav Nationality Matter). ${ }^{3}$ This bifurcation of his public life provides a useful yardstick, but may be a little incomplete. Reform legislation and the nationality question were not isolated, but related and intertwined, events. Enactment of Wesselényi's program was complicated by the demographic reality that more than fifty per cent of the Hungarian population was non-Magyar. ${ }^{4}$ The nationality issue was an obstacle to the passage of reform legislation in a nation led by a feudal Magyar ruling elite. Yet Szózat's plan to pacify the non-Magyars was to offer them the very constitutional rights Balitéletekröl had already outlined a decade earlier.

Another problem with the two-part analysis is its assumption that Wesselényi retained his Szózat views until he died in 1850. More recent scholars claim that in 1848, Wesselényi modified some of his Szózat views regarding the Romanians and the South Slavs. These writers suggest that after 1848, Wesselényi doubted whether such groups would remain in Hungary and proposed the nation should go forward without them. ${ }^{5}$

Rather than compartmentalize Wesselényi's public life into just the two periods, a more complete analysis of his nationality ideas might consider:

1) the pre-1830 formative years during which he shaped a rough vision of a Hungarian and Transylvanian political renaissance; 
2) the 1830-38 period highlighted by his confidence in liberalism, land reforms and constitutionalism all of which he believed would modernize Hungary; ${ }^{6}$

3 ) the 1840-47 years dominated by the nationality issue; and finally,

4) the 1848-49 Revolution years in which he became at least partly disillusioned with some of his earlier assumptions and concluded that a number of the nationality groups were unlikely to remain as part of the Hungarian nation.

The leitmotif of Wesselényi's public life was the need for a Hungarian national revival. But three important sub-themes were interwoven within that dominant idea: hope characterized the 1830-36 years; angst colored 1840-47, and resignation to reality settled over him during his last years. Seen together these three themes offer a kind of kaleidoscope which may help us better understand him.

\section{Prelude and Preparation}

Baron Miklós Wesselényi (the younger) was born on December 30, 1796 in the family castle at Zsibó, Közép-Szolnok county, Transylvania. The Wesselényi family had been prominent in Transylvania for centuries, although often controversial and not always kaisertreu. Wesselényi's father (also named Miklós) was an intriguing figure who was influenced by both the Enlightenment and Magyar nationalism. Zsigmond Kemény wrote of him that he was "a restless soul like a stormy petrel, who yearned for the storm and for excitement which he endeavored to satisfy with every breath." In 1792, Transylvania's Diet met to consider the Supplex libellus Valachorum, which proposed that the region's Romanians be treated as a nation equal to the three historic national groups. Midway through the reading of Supplex a fire bell rang outside causing many delegates to rush from their seats to see what was burning. Amid all this turmoil, the elder Wesselényi climbed on his desk and called on the delegates to return as there was already fire enough to put out within their own hall. ${ }^{8}$ Ironically, a larger nationality fire would erupt in Transylvania in 1848-49, despite the efforts of his son to avert it.

During young Wesselényi's lifetime, Hungary and Transylvania were caught between currents of change and historic inertia. One factor was a rapid population growth which altered the nation's demographic composition. After the Austrian expulsion of the Ottomans from the Habsburg lands, there was a significant population growth in both Hungary and Transylvania, much of which was due to an influx of non-Magyars. The figures are only approximations, but in the early eighteenth century there may have been about eight million people living in Hungary (including Croatia) and Transylvania. By 1850, the population in the same area had risen to nearly fourteen million souls. While the Magyars were easily the largest single ethnic group, comprising about forty per cent of the total inhabitants 
in the Kingdom of Hungary, there were more combined non-Magyar peoples than there were Magyars in Hungary. ${ }^{9}$ The Romanian population constituted an absolute majority in Transylvania. ${ }^{10}$

By the nineteenth century, Hungary had been touched by the Enlightenment, the Hungarian national awakening and a Magyar language revival. But the nation was also a product of its feudal past. While Hungary was part of the polyglot Habsburg Empire, it viewed itself as a separate kingdom within that realm. During the eighteenth century the Habsburgs tried to centralize their Empire, but Hungary retained considerable self-rule in its own domestic affairs. ${ }^{11}$ Hungary's feudal nobility dominated the nation's political, social and economic life. Approximately five per cent (perhaps 700,000) of the population was "noble," although "sandaled nobles" were often as poor as common folk. About 100,000 Hungarians could vote, while perhaps 30,000 were permitted to take an active part in politics. ${ }^{12}$ The bulk of the population lacked significant political or economic power. The country was primarily agrarian with rural peasants comprising approximately eighty to ninety per cent of its peoples. ${ }^{13}$ The non-Magyar peasantry was a concern, not simply because of its raw numbers, but because of budding tensions between the Magyars and the nationalities. ${ }^{14}$ During the reign of Emperor Josef II, national consciousness increased among both Magyars and at least some nationalities. To a degree Hungarian and Croat nationalism rose in reaction to the Emperor's reforms, while Romanian national aspirations were furthered by them. ${ }^{15}$

Transylvania had been part of medieval Hungary from the Árpád conquest until the Ottoman occupation of central Hungary during the sixteenth century. When middle Hungary was controlled by the Ottomans, Transylvania became semi-autonomous and experienced a kind of Golden Age which fostered Hungarian cultural continuity. After the Ottomans were driven out of Hungary in the late eighteenth century, and especially after the 1711 Treaty of Szatmár, Transylvania came under direct Habsburg control. ${ }^{16}$

Wesselényi was the only Transylvanian among the early Reform Age figures and one of the few who had lived among any of the nationalities. He entered Transylvanian politics in 1818-19 and became popular by opposing the kinds of reform he would later support. In 1818, the Empire tried to impose urbarial legislation on Transylvania's nobles while bypassing the traditional county assemblies. Wesselényi sided with the nobility in opposing the reforms and played a significant role in defeating them. ${ }^{17}$

A crucial factor in Wesselényi's political development was his early friendship with István Széchenyi, the "Greatest Hungarian." In 1823, Wesselényi and Széchenyi became friends with common interests and complementary strengths. ${ }^{18}$ During their travels through Europe the two decided to devote themselves to reviving Hungary by taking part in the nation's public life. ${ }^{19}$ In 1828 , each began 
writing a book, although Széchenyi's Hitel (Credit)was published while Wesselényi was still working on Balitéletekröl. Because of their close association and familiarity with each other's thoughts, there are similarities, even overlapping concepts, in the two works. Of these Wesselényi wrote:

Our feelings and opinions are so largely similar and both works are so similarly constructed that each of them could have been mine. ${ }^{20}$

The common themes caused Wesselényi both pleasure and sorrow, and for a time he considered not finishing his book since he feared Hitel made it superfluous. ${ }^{21}$

Even before Hitel appeared, the two friends had begun to drift apart. The basic dispute was over Hungary's relationship to Austria. Széchenyi was convinced that Hungary should continue to work within the Empire, while Wesselényi thought Austria was a major reason for Hungary's problems. Széchenyi wrote that while he saw "only a donkey's long ears," Wesselényi perceived "devil's horns" behind every act of Vienna. ${ }^{22}$ The issue came to a head in late 1831, when Széchenyi wrote Wesselényi:

I see that our paths have branched apart ... we simply do not travel on the same road [anymore]..$^{23}$

By 1830 , his life's preparatory phase had ended, and a not yet thirty-five-year old Miklós Wesselényi strode from the wings to the center stage of Hungarian politics.

\section{The Period of Hope}

Only the liberal program can save Hungary from the consequences of its oppression of the nationalities over the centuries. This can be done by giving all citizens of the nation full legal rights without regard to their class ranks or national differences. ${ }^{24}$

Although reforms came haltingly at first, the 1830 years ushered in a new era for Hungary. ${ }^{25}$ During the first half of the 1830s Wesselényi enjoyed his greatest political influence. He purchased lands in Hungary so that he could participate in the Upper House of the Hungarian Diet and soon became a leader in the "ellenzéki" or opposition group. That faction was vocal in the 1830 Diet but was unable to pass significant reform legislation. When Wesselényi tried to put together a parliamentary coalition to enact a program of liberal reform legislation, he thereby antagonized the Habsburg government in Vienna. ${ }^{26}$ In the 1832-36 Reform Diet, he emerged as a major opposition leader and proposed a comprehensive social 
and political reform program. However, his efforts were crowned with only limited success. Peasants were relieved from minor burdens, but the essence of his program was enacted only years later. ${ }^{27}$ Midway through the Diet's term, Wesselényi left Hungary for Transyvania to build support for liberal reform there and the reunification of Transylvania with Hungary. When he returned in 1835, Kossuth and Deák had assumed leadership of the opposition group. ${ }^{28}$

In his speeches, Wesselényi generally did not address the nationality question as such. But forcible recruitment of peasant soldiers, land reform and equality under law were issues with strong nationality overtones. He emphasized the need for reforms, but did not advocate universal suffrage or dividing the nation along ethnic lines. He wanted Hungary to be Magyar and nobility driven. ${ }^{29}$ If his reforms were adopted, he believed, an almost idyllic society would emerge, but he warned of dangers if change did not occur. ${ }^{30}$ Much of his reform program is found in his 1830-36 speeches and in Balitéletekröl.

Perhaps the greatest speech Wesselényi ever made was his January, 1833 "Sybil" speech to the Diet in which he emphasized the urgency of reform legislation. He spoke of the mythical Sybil who appeared in antiquity with her books of wisdom. Each time she proffered her volumes, she was rejected because her price was too high. After each rebuff she burned three of her books. Wesselényi likened prior Diets to the ancients who spurned the Sybil and he criticized earlier nobles for blocking peasant reforms. The Sybil was appearing for the last time; a rejection of her last offer would spell doom:

... Following her Christian duty, Marie Therese was ... forced to further this cause apart from the Diet. True, she acted illegally, but did so for the higher good of mankind, which is the highest law. It was then that the Sybil appeared to our nation the first time offering her nine books. But we found them too expensive, rejected them and thus, three of her books were thrown into the flames.

In the last quarter of the previous century, Josef [II] ... [also] by an unlawful action which still deserves blessing, abolished serfdom, this blight on humanity. In 1790, the Empire's Councils approved this action and began consultations about relieving conditions of the peasantry. It was then, that the Sybil appeared a second time, offering now her six remaining books. But we found them too expensive and so she threw three more books in the fire leaving her with only three books left. We should have abolished serfdom, eliminated all of its remnants, and washed off its filth in order to save the peasantry from the burdens of oppression and insecurity which pressed upon their person and landholding [rooted] in serfdom; instead, we clumsily abandoned the laudable work, referring it to committees for fortytwo years. 
Today the Sybil reappears with her last three books. We must not allow these [last three books] to be thrown into the flames, for I declare before heaven that if these burn to ashes, our homeland will be wasted and consumed. ${ }^{31}$

The "peasant question" was the most important socio-political issue Wesselényi's reformers faced. ${ }^{32}$ The problem included the need to: 1) ease or abolish archaic feudal dues and services which peasants owed landlords; 2) enact reforms so peasants could own some of the land on which they worked; 3) reform or abolish the nobles' immunity from taxation and create more equitable tax burdens; and 4) abolish serfdom. Peasant land reforms were inextricably intertwined with the nationality question. The latter complicated the former, but one could not be resolved without the other. Nationality and peasants' issues were often simply different sides of the same coin. ${ }^{33}$ Wesselényi feared the prospect of peasant revolt and believed that unless the nation took prompt steps to reduce discontent, it faced potentially dangerous consequences. He proposed to defuse the underlying causes of peasant resentment by a gradually implemented land reform program in which peasants would make redemption payments for the property they would acquire. This son of the "stormy petrel" wanted to restructure Hungarian society by progressive, peaceful consensus rather than abrupt social upheaval. ${ }^{34}$

In 1831, Wesselényi announced that minor revisions to the robot and feudal dues would be insufficient since peasants needed to actually own some lands on which they worked. ${ }^{35}$ In his Sybil speech, he attacked feudal dues and an outmoded legal system which gave landowners excessive controls over the peasantry. The nobles' exemption from taxation was fundamentally unfair. Those who earned the least should not have to bear the heaviest tax burden. ${ }^{36}$ In a November 10, 1833 speech in Szatmár county, he deplored landowner oppression of the peasantry and called for a revision of feudal laws which caused indescribable peasant misery. Owners were being unjustly enriched by peasant payments and services, yet the peasantry paid most of the nation's taxes and supplied the bulk of its soldiers. He attacked an ossified legal system which allowed a small privileged minority to unjustly dominate millions of fellow citizens. ${ }^{37}$

If the peasant question were the most pressing issue Wesselényi's liberals faced, the idea of equality before the law was both the crown jewel and the Gordian knot of their program. The basic concept was that all Hungary's citizens should stand equally before the law, regardless of class, religion or nationality. This legal equality required that the nobles give up some of their previously exclusive power, even though they still would play a major role in the nation's political transformation. Hungary's progressive nobility would continue to define the Magyar "nation." If by revolution or election the nobility were supplanted, their place would most likely be taken by non-Magyars, and Hungary would cease to be Hungarian. ${ }^{38}$ But 
legal equality was necessary for those Hungarian and non-Magyar citizens who had previously been victimized: “... [T] he yoke of tyranny must oppress no one; the shield of the law must protect everyone equally." ${ }^{39}$ He yearned for a Hungarian national state, but if that state's survival:

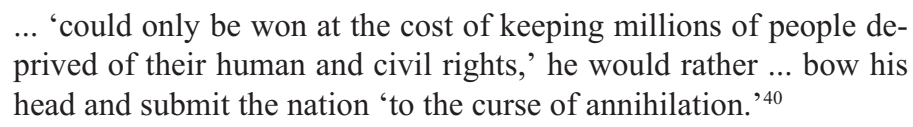

Wesselényi hoped that if the nation implemented constitutional reforms and full legal equality, the nationalities would voluntarily choose to become assimilated Magyars. ${ }^{41}$

He criticized government recruitment and impressment practices by which military age males (often peasants) were involuntarily forced into the army ${ }^{42}$ Such heavy-handed actions dislocated lives and ripped apart peasant households. In an October, 1830 speech, Wesselényi deplored the impressment practices used by the government and detailed the economic hardship and domestic trauma they created. ${ }^{43}$ In 1831, he boldly (and perhaps intemperately) announced that on his own lands in Transylvania he would personally resist any governmental attempts to draft unwilling peasants in the army. ${ }^{44}$ In January of 1833, he told the Diet that forcing non-consenting peasants into the army constituted both landowner and state oppression. Later that same year he informed a county assembly that feudal privileges which allowed landlords the right to force unwilling peasants into military service was a classic unjust dominion exercised by the few over the millions. ${ }^{45}$

But in the 1830s, Wesselényi also took positions on two issues which irritated at least some nationalities. The first of these was his belief that Magyar, rather than Latin, should be the official governmental language in Hungary. With his strong support, the Reform Diet passed a law which made Hungarian the official governmental language in certain situations. The Croats expressed their bitter objection. ${ }^{46}$ Secondly, in the mid-1830s, Wesselényi was a major figure in an attempt to bring about the reunification of Transylvania with Hungary. While he proposed that reunification be conditioned upon Transylvania's Diet granting liberal peasant rights and land reforms, and that any future merger had to be approved by Transylvania's Diet with royal approval, some of the nationalities were alarmed at the prospect of a Transylvanian reunification.

Wesselényi completed Balitéletekröl in 1831, but it was not printed until 1833 because of censorship problems and printing delays. ${ }^{47}$ As its title indicates, the work identifies types of distorted perceptions which cause faulty decisions. Its chapters are arranged according to kinds of prejudices people have (i.e., "Misjudgments of Birth and Political Status," etc.). While many of Wesselényi's reform concepts are contained in Balitéletekröl, ${ }^{48}$ they are not specifically identi- 
fied by chapter headings, but interspersed throughout the work, often as solutions to various kinds of muddled thinking. ${ }^{49}$

Wesselényi specifically raised the nationality question in Balitéletekröl, although of the book's nearly three hundred pages only a few deal with it. His primary purpose was to identify the divisive ethnic tensions which were splitting Hungary into factions. In Balitéletekröl, he described the problem, but also presented in embryo basic concepts which later dominated Szózat. ${ }^{50}$ Wesselényi mused:

Imagine what we could do in Hungary if the multitude of different national groups and religions would overcome all of these conflicting view-points and petty prejudices so that all of the nation's citizens, regardless of nationality, could join hands to bring about unity and a single national state by sacrificing their mutual animosities and suspicions upon the nation's altar? ${ }^{51}$

He was profoundly troubled by the ethnic contention he observed:

We have among us all kinds of languages, many religions, countless different customs and many nationality types. And therein lies the danger. It is difficult, if not impossible, to bridge all of these differences. Only a [single] national fervor for the homeland, the law and the constitution can bridge these contentions by extending constitutional blessings to all these disparate tongues, religions and national groups. Only thus can we achieve the result that no one [ethnic] group can harm or torment another. ${ }^{52}$

While Balitéletekröl illustrates, rather than solves, the nationality problem, Wesselényi suggested that "the homeland, the law and the constitution" could create a unified nation. Constitutionalism would dominate his later Szózat, but Balitéletekröl presaged its theme. At a time when rising nationalism was just beginning to surface, he saw the wisdom of trying to build a broad national consensus in a multi-national state:

... Blessed is every effort which tries to root out the prejudices and differences which pit one nationality against another and tries to resolve national separations. On the other hand, that which breeds separation and incites national passions, even when done in jest, is detestable and harmful..$^{53}$

Wesselényi's early nationality ideas expressed the Hungarian liberal position and exposed its basic contradictions. By the 1830 s, some ethnic consciousness had already surfaced among Hungary's nationalities. In opting for a "one nation, one language" pattern borrowed from Western Europe, Wesselényi and his liberals may have chosen a model which would not work in multi-lingual, multi-cultural Hungary. While he and the liberal reformers wanted to extend broad consti- 
tutional rights to the nationalities, the "nation" they intended to create was to be Magyar centered:

On the one hand, there was implicit in their dedication to civil rights for all an impetus to the national development of every ethnic group; on the other, there was their determination to recognize as a nation with collective rights no ethnic group within the country but the Hungarian. This, in a nutshell, was the irreconcilable internal contradiction at the heart of liberal nationalism. ${ }^{54}$

In Balitéletekröl Wesselényi also addressed the need for land and tax reform. There were two major flaws in Hungary's constitution: 1) the lack of legal protection for the peasantry; and 2) the nobles' immunity from taxation. ${ }^{55}$ Put simply the issue was:

... As soon as possible, the nation should allow its peasants to have title interests in lands upon which they work and to become landowners under uncomplicated conditions. ${ }^{56}$

Reforms needed to come about incrementally rather than by revolution, as abrupt changes engender national instability. But they needed to begin lest the lower economic classes become desperate. ${ }^{57} \mathrm{He}$ proposed a uniform formula for determining how peasants should pay for land and a similar schedule for property redemption payments. The goal was for peasants to eventually own at least part of the land on which they worked, freed from feudal dues and services. ${ }^{58}$ But Wesselényi's solution to the peasant problem was more than just removing economic restraints. The nation needed to lift up its peasants, abolish conditions which impoverished them, and repeal the feudal system which allowed nobles to exploit peasant labor. There were deeper social factors since poverty carried within itself destructive seeds of oppression. Servitude followed in the wake of poverty, enfeebling the soul and weakening the state. But economic freedom would provide an opportunity for secure financial life and mental development. ${ }^{59}$

The other major economic problem was the nobles' immunity from taxation. Wesselényi boldly announced: "I say publicly that we, the Hungarian nobility, must pay taxes." While some imagined that freedom required nobles to be exempt from taxation, those with the highest incomes and abilities also needed to make financial contributions toward the national good. Every citizen had the obligation to pay taxes; each was also entitled to develop its wealth without stifling feudal burdens. ${ }^{60}$

Balitéletekröl echoed Wesselényi's basic theme that all Hungarians should be equal under law. Sometimes he addressed the equality issue indirectly while criticizing prejudices grounded in pedigree (kutyabör) or wealth which denied civic equality to those not nobly born. ${ }^{61}$ Depriving a person of basic legal rights was 
tyranny because all were entitled to a fair reward for their honest labor. To the oppressed he wrote:

... Peasant, dry thy tears! In the stirrings of the nation's noblest hearts the dawn is breaking. The time is here and the age is now when the law offers you a fate worthy of your human existence and merit. ${ }^{62}$

The greatest freedom existed where the interests of all were guarded by properly appointed representatives. But reforms which existed only on paper would not suffice:

... Standing alone, neither statutes, constitutions nor favorable politi-
cal conditions enrich a nation. Unless as a result of inner develop-
ment and progress a legislative program is given life, the wisest law
will remain a dead letter; the strongest government will simply die a
painful death. Public order and constitutions do not always produce a
national spirit. Rather, spiritual and moral progress is that which in-
exorably carries good laws along with it ... ${ }^{63}$

Although at times it is critical of the status quo, Balitéletekröl's message is optimistic. There were serious problems in Hungarian society, but Wesselényi was confident of his remedy. If the nation would make the needed changes, Hungary could have land reforms which provided security for both peasants and landlords, equality of the nationalities under law, more equitable taxation, credit reforms to stimulate the nation's economic growth, the abolition of feudalism, a constitution which guaranteed human rights, and freedom of the press ${ }^{64}$ Reality was different, but when Wesselényi finished his book, he was hopeful that Hungary stood at the threshold of a new age.

In 1835 and 1836, criminal actions were filed against Wesselényi in Transylvania and Hungary. Metternich saw him as a dangerous radical who needed to be heeled. ${ }^{65}$ The government claimed that in November, 1833, and December, 1834 (both in legislative sessions), Wesselényi made treasonous speeches. ${ }^{66}$ The specter of the trials haunted him and undermined his health. On October 18, 1837, Széchenyi wrote that he had met with Wesselényi and that "... the poor devil looks as if he had already spent ten years in prison.." ${ }^{\prime 67}$ In March, 1838, while awaiting his trial verdict, Wesselényi was in Pest when a massive Danube flood inundated the city and destroyed almost half of its houses. He requisitioned a boat and spent the next 72 hours rescuing trapped souls and rowing them to safety, personally saving some six hundred people from a watery grave. In February, 1839, Wesselényi was sentenced to serve three years in prison. During that imprisonment, first in Buda, then in Gräfenberg, Bohemia, he began to go blind. After serving less than a year in prison he was pardoned, but never again regained his earlier political influence. At Gräfenberg he was treated to save his failing eyesight, but by 1844 , he was 
almost completely blind. ${ }^{68}$ Wesselényi's "Era of Hope" ended with imprisonment and blindness. His parliamentary achievements were mostly symbolic, but if his dream of the 1830s was not attained then, neither did it die. Although he was no longer a major political figure, a number of his reform ideas were adopted in 1848 .

\title{
IV. The Period of Anxiety
}

\begin{abstract}
... I tell you that now is the midnight hour of danger. And I will tell you the cause of the danger. The threat has ripened, and for that reason Europe needs to be on guard. The Northern Giant [Russia] threatens both present and future conditions which weigh heavily upon Europe. And I shall tell you, and particularly our homeland, what that danger is and what must be done to withstand the threatening peril. $^{69}$
\end{abstract}

Increasingly engulfed in a world darkened by blindness, politically emasculated and largely forgotten in Hungary, Wesselényi began the 1840s broken and enfeebled. But soon he began to focus on the nationality topic which would dominate his life's last decade. Gräfenberg spa attracted notable people from all around as Germans, Czechs, Poles, South Slavs, Romanians, Russians and Western Europeans gathered to "take the waters." Because of his imprisonment and health Wesselényi's actions were somewhat limited, but he could still talk to people. He joined the casino at Gräfenberg and met intellectuals from other Central European nations who discussed with him the Slavic awakening and its potential meaning for Europe. He paid particular attention to their observations about Hungary and its non-Magyar peoples. At Gräfenberg many of his Szózat ideas ripened, enriched by the thoughts of those with whom he shared ideas. ${ }^{70}$

After 1836, Kossuth and others advocated a more aggressive agenda with respect to both the nationalities and Austria. The focal issue of whether Magyar should become Hungary's official language widened the gap between Magyars and some nationalities. ${ }^{71}$ Efforts to assimilate Hungary's ethnic groups intensified, but a number of Slavs and Romanians were awakening to their own ethnic consciousness. By the time serious "Magyarization" actually began, some nationalities were strong enough to resist. ${ }^{72}$

After his release from prison Wesselényi wrote a December 8, 1842 newspaper article in Pesti Hirlap in which he attacked Széchenyi's earlier speech on the nationality issue at the Magyar Tudományos Akadémia. Széchenyi's speech criticized Kossuth and Pulszky and claimed that their chauvinist attempts to assimilate the nationalities had damaged Hungary's reputation abroad and hardened non- 
Magyar opposition at home. ${ }^{73}$ He implied that the Slav nationality movements had arisen as a reaction to these heavy-handed "Magyarization" and language efforts. Wesselényi responded hotly:

... I declare that this [Széchenyi's] statement that the Slavic movement is a reaction caused by excessive Hungarian language zeal is without foundation ... and these false statements make us hated at home and abroad ... Besides that, the Slav movement threatens both our homeland and all of Europe with grave danger ...

... I deny that Hungarians who cherish the spirit of constitutional freedom would tolerate or could tolerate persecution or hatred of the Slavs by any overzealous efforts. And I firmly state that those who try to stir up our nation by acts of force or oppression against foreigners or other nationalities violate the dictates of law and reason. But in the same vein, those who would work against the Hungarian language and people or who knowingly or unknowingly promote movements contrary to our nation, are enemies of our most sacred interests. $^{74}$

Despite Wesselényi's florid language, there were substantial similarities in the positions of the two former friends. They did disagree about what caused the rise of the Slavic movements, but they acknowledged that the failure to timely extend civil rights to nationalities had created a major problem. Each admitted that a policy of overzealous Magyarization was ethically and logically wrong. They both conceded that the Slavs had legitimate grievances and suggested the need for caution and patience in dealing with them and that a too vigorous attempt at assimilation would not succeed.

Wesselényi began to write Szózat in early 1841, but ill health and poor vision slowed his efforts. Despite his growing blindness, Wesselényi finished the book in 1843 and sent it to the printer in Leipzig where it was published later that year. $^{75}$

Szózat begins with Wesselényi calling himself "civically dead," an outcast cut off from the circle of active politics. He had been one of his nation's brightest lights, but because of illness he could no longer play that role. ${ }^{76}$ But notwithstanding his physical afflictions he must try to awaken his country to the danger which threatens it:

... For out of the grave the spectral voice sounds the alarm. Danger threatens, Oh Homeland! Danger such as there has never been before. ${ }^{77}$

He called upon the nation to awaken and heed the impending threat or it would perish. Wesselényi believed the root cause of the nationality problem was the Magyar nobility's failure to allow nationalities the right to participate in Hunga- 
ry's political system. For nearly a millennium the Hungarian ruling class had failed to allow the nation's non-Magyars any significant voice in government or society. ${ }^{78}$ Centuries of shortsighted exclusion by the Magyar aristocracy had oppressed the nationalities and made them resentful. As a result, the country's non-Magyars had become estranged and Hungary was a powder keg ready to explode. The nation's situation might have been totally different had the conquering Árpáds not treated the non-Magyars as merely subject peoples. How much wiser it would have been to grant them full Hungarian citizenship. ${ }^{79}$ Instead, a few hundred thousand privileged people held total political power while many millions lacked basic civic protections. But the ruling elite had also made paupers of Hungarians who were not nobles. As a result, the non-Magyars and most ethnic Hungarians were excluded from government and deprived of constitutional rights. ${ }^{80}$ The consequence of this narrow-minded elitism was a legacy of bitterness. But in the nineteenth century new forces had arisen, partly as an outgrowth of the French Revolution, including yearnings for constitutionalism and greater political freedom. These feelings fostered ethnic consciousness and aspirations for self-determination. ${ }^{81}$ Powerful external propaganda forces had stirred these yearnings, all of which presaged disaster for Hungary and the Habsburg Empire unless past mistakes were rectified.

Wesselényi was among the first to sense a danger in the growing discontent among Hungary's nationalities. Some scholars have questioned his premise that the root cause of nationality unrest in mid-nineteenth century Hungary was the Árpád conquerors' failure to grant citizenship to the conquered peoples nearly a millennium earlier ${ }^{82}$ At the time of the Conquest, Magyar society was tribal, rather than feudal. It would have been unusual for any European people in the tenth century to offer full civic rights to peoples they had just vanquished. Wesselényi may have overlooked the reality that Hungarian society had permitted some nonMagyar membership in the nation's nobility. A survey dated near the time Wesselényi wrote Szózat suggested that perhaps fifteen per cent of the nation's nobility was non-Magyar and did not speak Hungarian. ${ }^{83}$ However, the crucial factor is not whether the nationality estrangement had its roots in early Árpád times or later ones, but Wesselényi's observation that the nationalities (and Magyar non-nobles) had long been systematically excluded from participation in the nation's political process and deprived of legal protections in Hungarian society. One may question Wesselényi's postulates, but he accurately concluded that an unresolved nationality problem posed an increasingly serious danger for multinational Hungary.

A major Wesselényi purpose in writing Szózat was to expose what he saw as a Russian attempt to manipulate the Pan-Slav and Illyrian movements in order to weaken Slavic ties to Hungary and Austria ${ }^{84}$ He reiterated his Balitéletekröl opinion that Slavs distrusted each other because of their conflicting national aspira- 
tions and traditions. ${ }^{85}$ Because of past injustices suffered by Slavs and Romanians, Wesselényi was convinced they held strong negative feelings toward Austria and Hungary. He felt that because of their similar Slavic languages and cultural heritages the Hungarian Slavs looked to Russia as a more likely protector of their nationality aspirations than either Austria or Hungary. ${ }^{86}$ As Ottoman power waned in Southeastern Europe, he feared Russia would fill the resulting vacuum with the help of the South Slavs. This expansion into the South Slav regions posed a dire threat to both the Empire and to Hungary. ${ }^{87}$

Wesselényi believed there were two kinds of Slav propaganda which undermined South Slav loyalty to Hungary: 1) Russian (by far the most dangerous); and 2) Western Slav (mostly Polish) which advocated the creation of several independent Slavic states in Central Europe. In the end, both would inure to Russia's benefit. ${ }^{88}$ He feared Russia would either swallow whole the smaller Slavic peoples, thereby making them part of a Greater Russia; or that it would fashion a weak assemblage of Slavic puppet nations. Such politically non-viable mini-states would be inescapably drawn into the Russian orbit because they could not independently survive without Russia's protection. He believed Russia was the blackhatted villain whose propaganda aimed at weakening multi-national states with large Slavic populations (such as Austria and Hungary). At the same time, the tsar tried to solidify pro-Russian feeling among Slavs prior to the outbreak of what Wesselényi felt would be an inevitable great war between Austria and Russia. ${ }^{89}$ The Russian danger was serious for all Europe, but absolutely life-threatening to status-quo nations such as Austria and Hungary with large Slavic minorities. ${ }^{90}$

Wesselényi has been criticized for his belief that 1840s' Russia was the power behind the Pan-Slavic and Illyrian movements. ${ }^{91}$ For all the emphasis he placed upon the Russian danger, Szózat's author gives few specific instances of Russian propaganda efforts involving the Western Slavs. ${ }^{92}$ Non-Hungarian scholars of both Pan-Slavism and Illyrianism have suggested that there was little active Russian involvement in either movement during the $1830-50$ period. ${ }^{93}$ While Wesselényi correctly sensed there would be a future Russian threat to Hungary, the Russian action which undercut Hungary's 1848-49 Revolution was not the Great Northern Power's intervention in support of Hungary's Slavs but its fraternal assistance to its then ally, Austria. During Wesselényi's lifetime Hungary's struggle was primarily directed at Austria, not its nationalities (although Transylvania's Romanians, the Croats and Serbs fought against Hungary in 1848-49).

Of the nationalities treated in Szózat, Wesselényi's views about the Transylvanian Romanians were the most faulty in their short-term perceptions yet most accurate for the future. His thoughts meandered through three difficult to reconcile themes: 1) a similar Uniate-Orthodox cultural and linguistic tradition; 2) a RomanianRussian cultural connection; and 3) a Transylvanian Romanian affinity toward Moldavia and Wallachia which he feared would lead to the eventual creation of a 
Greater Romania. While his theories were not always consistent, he may have been the first Hungarian to see the possibility of a potential Romanian threat to Hungary. ${ }^{94}$

Wesselényi believed that Transylvania's Romanians, both Uniate and Orthodox, had similar traditions which united them in the face of persecution by those who neither understood them nor shared their beliefs. He wrote of the Romanians' "... common suffering and mutually oppressive fate" which increased their own national feelings..$^{95} \mathrm{He}$ also conceded that Transylvania's Romanians had cause for anti-Magyar bitterness and that they might already be irretrievably alienated from Hungary. Hinting at the theme of his 1848 Klauzál letter, Wesselényi questioned the loyalty of Transylvania's Romanians to Hungary. He also thought that the Romanians in Hungary had strong cultural ties to Russia on account of their similar eastern orthodox faiths. If a future war were to break out between Russia and Austria, he believed the Romanians would likely side with Russia because of their common religious beliefs. ${ }^{96}$ Wesselényi's most intriguing observation was his concern that in some future time, the Transylvanian Romanians would join with Wallachia and Moldavia in forming a Greater Romania. ${ }^{97}$

Wesselényi's Romanian observations have evoked negative scholarly comment. Trócsányi notes that Szózat only hints at the historic oppression of the Transylvanian Romanians by the Hungarian nobility and the consistent exclusion of Romanians from Transylvanian politics. ${ }^{98}$ Others assert that Wesselényi misperceived Transylvanian-Romanian aspirations of the time and overestimated the danger of a Russo-Romanian alliance grounded upon an orthodox faith orientation. ${ }^{99}$ While one modern scholar claims that Wesselényi based his opinion on ethnicity and geography, rather than on facts, ${ }^{100}$ Wesselényi's fear of a Greater Romania and its grave implications for Hungary became reality after the 1919 Treaty of Trianon. Some of his Romanian perceptions were flawed, but in light of later developments Wesselényi should be given credit for observing what were perhaps the first stages of later powerful trends.

To counteract the Russian propaganda Wesselényi returned to his Balitéletekröl ideas of constitutionalism. He was convinced that the "infallible" tools which would win over the nationalities to Hungary were guaranteed constitutional rights and full equality before the law. If Hungary would give her non-Magyars these political freedoms, they would see they had more to gain by staying in the Empire than by allying with Russia. Thus, Russian influence over the South Slavs would cease. ${ }^{101}$ The task was to convince the Slavs that Hungary would not deprive them of their national languages or traditions, but would accept them as full participatory members in a new Hungarian society in which ancient prejudices were replaced by constitutionalism and mutual respect. ${ }^{102}$

Wesselényi pled for a more humane, equitable Hungary. If part of a nation's people is oppressed, that nation will not be great even if a dominant group has a 
strong national consciousness. Those who would subordinate or sacrifice nationality rights in the name of state interests, merely play into the hands of the Slav or Illyrian movements. ${ }^{103}$

Perhaps Szózat's most controversial feature was its proposal that the Habsburg Empire be transformed into a constitutional confederation which would consist of five governmental units all loosely bound to the Habsburg monarch, but with rather broad local autonomy. ${ }^{104}$ Wesselényi believed this reconfiguration would counteract Russian threats and honor nationality aspirations. ${ }^{105}$ Under his plan the Austrian section of the Empire would be split in four parts, while the Hungarian portion would be expanded by adding Transylvania. The South Slavs, Slovaks and Romanians would stay in Hungary rather than form separate administrative units of their own. Even a brief glimpse of this plan discloses two major problems: 1) Austria would almost surely have had significant reservations about being carved in pieces while Hungary not only remained intact, but expanded; and 2) the Serbs, Croats and Romanians would likely have strongly objected to staying in Hungary while other nationality groups were given autonomy.

Nonetheless, Wesselényi assumed that if the Empire were reconstructed into the five federative components, peoples who had historically opposed each other would become allies, thus decreasing ethnic tensions. ${ }^{106}$ The Empire would become a symbol of freedom instead of reaction and would also strengthen itself for a later battle with Russia. While Russia might attempt to evoke vague notions of Slavic kinship, she could not offer the Slavs constitutional protections or a meaningful role in its government. ${ }^{107}$

From today's perspective, Wesselényi's proposed solutions to the nationality problem seem rather utopian in light of what happened afterward. His confederation idea was almost surely impractical and had no real chance of adoption. The linchpin of Szózat, that constitutionalism would have stronger appeal to the nonMagyars than Slavic or Romanian nationalism, was almost surely erroneous. With remarkable incisiveness, Professor Varga observes:

... [A] number of Hungary's ethnic groups already had a national consciousness strong enough for their leaders to have set their sights on building their own nations, and these same men were hardly likely to consider national rights an acceptable price to pay for civil liberty. In fact, their reaction to the idea of "constitutional" Magyarization and to attempts to spread the use of the Hungarian language left no doubt that the proposed "liberties" were hardly attractive enough for them to subscribe to the "one nation" principle. As Károly Nagy aptly noted, equal rights would not engender jubilant ethnic groups rushing to assimilate to the Hungarians. ${ }^{108}$

One other Szózat point is worth noting. Wesselényi perceived that Hungary was geographically vulnerable because she was surrounded by Slavs and Roma- 
nians who he felt would be probable Russian allies if war came. ${ }^{109}$ The nation was surrounded by ethnic groups and the nationalities held the high ground which encircled the country. When the Magyars came into Hungary, they had settled on the fertile plains, leaving the mountainous, agriculturally less productive areas to the nationalities. From a military point of view these mountains were of obvious strategic advantage. ${ }^{110}$ If a Romanian or Slav invasion of Hungary occurred, he worried that the invaders might form states or confederations which would be built on the ruins of historic Hungary. All or part of Hungary would then be ruled by enemies who would either destroy the nation or create new states out of what had been old Hungary. The Magyars would be confined to a truncated part of central Hungary which would be reduced to a minor power. ${ }^{111}$ Wesselényi also saw a cloudy future for Austria. With haunting acuity he wrote:

... Austria's existence can be maintained best by peace; war,even a victorious war, may well result in her annihilation. ${ }^{112}$

Szózat certainly has weaknesses in both its analysis of the nationality problem and in its proposed solutions. But while fairness requires that we disclose its faults, we should also acknowledge its strengths. Wesselényi observed that his own aristocratic class had drawn the circle of political participation too tightly, particularly in an age of the French Revolution and national consciousness. The sins of the fathers could be visited upon the sons unless changes were made in the way Hungary treated its non-Magyar nationalities. Wesselényi's flaws in short-term vision have already been noted, but he accurately foresaw the direction in which nationality movements were headed and the dangers these movements posed to Hungary if a solution were not found to the nationality problem. He sensed that Russia would try to expand its influence into the Balkans, and that it would justify its actions by claiming to be the protector of the Slavs. He saw Hungary's vulnerability in the event of a major European war and feared that the minorities would try to create national states out of historic Hungary, leaving the Magyars confined to middle Hungary. Szózat raised issues which were central to Hungary's survival as a multi-national state, but in 1843 , no one wanted to listen to a "civically dead" blind man who called for moderation in an age of rising nationalism.

\section{The Period of Reality}

The lack of interest in Szózat was a tremendous disappointment for Wesselényi. However, when the March 1848 Revolution broke out in Hungary, he was given a brief new political life and again became active in Transylvanian politics. On April 12, 1848, he warned Hungary's Transylvanians that the Romanian peasants there would react angrily unless feudal laws were abolished and land reforms 
enacted. Otherwise he feared that the Romanians in Transylvania would join Moldavia and Wallachia and try to create a new Romanian state which would include at least part of Transylvania. ${ }^{113}$ On June 6, 1848, he addressed Transylvania's Diet which had abolished some of the relics of feudalism. Wesselényi recalled the lives of those who had suffered under laws which impoverished those who worked and enriched those who did not. He concluded:

\begin{abstract}
... My prayer is this. That we raise up to ourselves those who have suffered so much already. Let us raise them to where God created them. Let Transylvania's peasants and serfs no longer be the oppressed, the people of the dust, the misera plebs, but rather let them be free citizens. Let them be equal with us in responsibility and may they be constitutionally empowered fellow citizens who stand equally before the law; let them have the same legal rights and common freedoms that we do, and thus serve their homeland and be called our brothers in defending her. ${ }^{114}$
\end{abstract}

But the Romanians, who originally supported the revolution, began to turn away, at least partly because of an unwillingness of Hungary's leaders to negotiate with them. ${ }^{115}$ Almost immediately after the Austrian government agreed to Hungary's 1848 proposals for internal self-rule, the Croats became hostile. By the late spring of 1848, Croatia's Ban, Josip Jellačić, assembled South Slav forces to invade Hungary. On April 20, 1848, Wesselényi wrote Hungary's new Prime Minister, Lajos Batthyány, to share his concern that if war broke out between Croatia and Hungary, Russia might become involved. ${ }^{116}$ Wesselényi emphasized the need to keep the conflict contained and that if the price for peace was greater Croatian autonomy, Hungary should cut its losses:

\footnotetext{
... I think we must avoid everything that might serve the Ban [Jellačić] and his Croats as an excuse to openly declare their secession and carry it through. We cannot keep Croatia for our own; let's give up all efforts to do so, which can bring no benefit, but can result in harm.

... Let's make an agreement with the Croats, one that recognizes them, and guarantees their independence, but guarantees also our trade and gives us joint ownership of a piece of coastline. ${ }^{117}$
}

His letter to Batthyány suggests Wesselényi recognized that his Szózat idea of constitutionalism would no longer work with the Croats. Whatever earlier opportunity there might have been to retain Croatia had been lost. And rather than jeopardize Hungary's political existence, he was prepared to allow Croatia to go its separate way.

Wesselényi was also concerned about events in Transylvania. On June18, 1848, he wrote Gábor Klauzál, the Hungarian Minister of Agriculture, Industry and 
Trade, ${ }^{118}$ that there were many ethnic Magyars living among Slovaks, Romanians, and Serbs who were needed as citizens of Hungary. There were also large numbers of Romanians in Transylvania and Hungary. If they wished, these Romanians could join with their Moldavian and Wallachian cousins in those areas of Transylvania where Romanians comprised a majority of the population. ${ }^{119}$ To resolve existing tensions Wesselényi proposed that Transylvania be peacefully partitioned along nationality lines, thus creating a Romanian Transylvania which would join with Wallachia and Moldavia, and a territorially smaller, but ethnically homogenous Hungarian Transylvania to be united with Hungary. The part of Transylvania which would belong to Hungary would consist of people who either considered themselves Hungarian or who wanted to be citizens of the Hungarian state. He assumed that the majority of Romanians in Transylvania would want to leave Hungary and become part of a new Romania. ${ }^{120}$ The consequence of more than a half-million Hungarians being submerged into a Romanian state could be avoided by this peaceful, voluntary partition. ${ }^{121}$

Wesselényi envisioned a consensual relocation and exchange of peoples in which Hungarians living in Transylvanian areas where Romanians predominated could trade homes and properties with Romanians "... who lived close to lands inhabited by Hungarians." He optimistically assumed that Transylvania's Szekelers and Germans would join the new Hungarian Transylvania. ${ }^{122}$ He was confident that this:

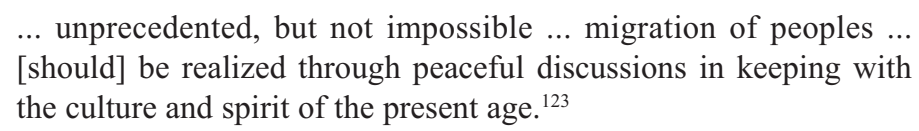

In conjunction with this transfer of peoples there could also be an adjustment of the political borders of Romanian and Hungarian Transylvania which would reflect the changes caused by these voluntary migrations. ${ }^{124}$

Wesselényi's ideas in the Klauzál letter seem to reflect his begrudging recognition that Romanian nationalism was a stronger force than constitutionalism or equality under the law. Klauzál did not respond to Wesselényi's letter. Hungary was plunging headlong into a military conflict which threatened its existence, so there was no chance in 1848-49 to seriously consider, let alone implement, Wesselényi's partition proposal.

In a final attempt to keep all of Transylvania within Hungary and pacify the Romanians there, on August 17, 1848, Wesselényi introduced a nationality bill in the Transylvanian Diet. On August 25, he spoke before the Upper House noting that the situation he had warned about in Szózat had become a horrible reality. In order to ease Romanian distrust, his nationality bill would show the Diet's good faith and grant full citizenship plus constitutional, religious and language protec- 
tions to Transylvania's Romanians. ${ }^{125}$ He told the Diet that passage of his bill was urgent:

... because I am convinced that this bill at the present moment is as crucial as it is useful ... I know that this bill will achieve what is vital for the interests of our homeland and the preservation of our nation, namely harmony and peace [in Transylvania]. ${ }^{126}$

Wesselényi's nationality bill was approved by Transylvania's Lower, but rejected by the Upper House. ${ }^{127}$ Thereafter, the situation in Transylvania took a bloody turn as many Romanians sided with Austria and took up arms against the Hungarians there.

With Hungary facing an imminent Austrian invasion, Wesselényi left his home in Transylvania and took his family to Gräfenberg. When the revolt collapsed in 1849, a gravely ill Wesselényi returned to Hungary, intending to die at Zsibó. On his journey home aboard a steamer, he contracted pneumonia and died in Pest on April 21, 1850. ${ }^{128}$

\section{Conclusion}

Perhaps the final question is simply: "What is there about Wesselényi's life that merits our attention a century and a half after his death?" He was not the scholar Eötvös was, not as effective a negotiator as Deák, not as attuned to the country's mood as was Kossuth, nor as brilliant a writer as Széchenyi. The latter spoke with some truth when he noted that Wesselényi continually tried to swim upstream. ${ }^{129}$ But his stubbornness was often born of a remarkably refined idealism. While one finds instances of his own class consciousness in his writings and speeches, more often his dominant concern was what would benefit the nation. Unlike Dessewffy, or perhaps even Kossuth, Wesselényi was more than a spokesman for his social class. And therein lies something enduring. There is statesmanship when a member of a privileged elite asks his group to voluntarily surrender some of its advantage for the overall good of the country. There is wisdom when a human tries not just to defend his own position, but listens to his opponent's argument in an attempt to find a mutually acceptable compromise.

Some of Wesselényi's writings and speeches reveal a far-seeing intellect. His Sybil speech and his June, 1848 speech on the abolition of serfdom in Transylvania are true masterpieces worthy of any nation's canon of great political oratory. Balitéletekröl's even-handed analysis of land reforms and its eloquent admonition for legal equality reveal a man who looked beyond the narrow interests of his own

social heritage. Szózat describes the unhappy consequences of an unresolved na- 
tionality conflict and contains a chilling portrait of a nation divided against itself. Amidst his dark fears, quantum leaps and premature calls for a confederation, one also finds a first-rate understanding of imploded nationalism's potentially destructive power and the challenge it poses to a multi-national state's social stability, if not to its very existence.

It might be intriguing to ponder whether timely adoption of his ideas could have altered subsequent Hungarian history. But prognostication is an extremely slippery subject with a dizzying array of variables. And when one must factor in the horrendous influence of World War I and the myopia of the post-war Western Powers, any opinion may be so fraught with hazard as to be worthless. An American-Hungarian historian suggests that by 1848 , it would have been "extremely difficult" to establish a permanent integration of the nationalities within the Empire and "impossible" thereafter. ${ }^{130}$ If that analysis is correct, Wesselényi's ideas may have come too late in any event.

This much seems certain. Wesselényi had a vision for a more humane Hungary. In the end, his inability to persuade his nation to adopt a more balanced nationality policy failed, not so much because of his lack of political adroitness, but because he was ahead of his time. He endured ridicule, imprisonment, blindness, and perhaps most painful, being ignored. The depth of his convictions are perhaps best shown in 1848, when this frail, blind, and forgotten "museum object" again charged into a battle for tolerance in his beloved Transylvania. Perhaps he deserves to be judged not just by achievements alone, but also by his struggles, by what he tried to do. Mankind's struggle to raise itself is a common theme in Hungarian literature. In the winter of 1859-60, another Hungarian whose life was also rent by the failed 1848-49 Revolution, wrote these words which he gave to a hero in his dramatic poem:

\footnotetext{
It's not ... fool illusions [that] drive me on. A hundred times I'll miss the goal, I know. No matter. Truth to tell, what is a goal?

[It is] the termination of a glorious fight. ... Life is struggle, strife, And it is [striving] itself that is man's goal. ${ }^{131}$
}

While Wesselényi's life ended in disappointment and darkness, his silent hand can be sensed not just in the 1848 April Laws, some of which survived the revolution, but in important legislation in 1868, ${ }^{132}$ and in Article 68 of a free and democratic Hungary's present constitution. ${ }^{133}$ Perhaps the most precious seeds are those which require time to germinate and sprout. Wesselényi's political legacy may have been overshadowed, but some of it remains today in the laws and life of the land he loved. 


\section{Notes}

1. Samu Kardos, Báró Wesselényi Miklós élete és munkái, 2 Vols. (Budapest: Légrády Testvérek Könyvnyomdája, 1905), 1:71; Zoltán Fónagy, Wesselényi Miklós. Válogatta, a bevezetést és a jegyzeteket írta Fónagy Zoltán; Magyar Szabadelvüek (Budapest: Új Mandátum Könyvkiadó, 1998-1999), 161.

2. Zsolt Trócsányi, Wesselényi Miklós (Budapest: Akadémiai Kiadó, 1965), 148. See also Gyula Barla, Kemény Zsigmond föbb eszméi 1849 elött. (Budapest: Akadémiai Kiadó, 1970), 41. Trócsányi claims that Széchenyi was more a traditionalist with liberal economic views than a classical liberal. For a contrary view see Mihály Szegedy-Maszák, "Enlightenment and Liberalism in the Works of Széchenyi, Kemény and Eötvös," in György Ránki (ed.), Hungary and European Civilization, Indiana University Studies of Hungary. Budapest: Adadémiai Kiadó, 1989), 12.

3. Miklós Asztalos, Wesselényi Miklós az első nemzetiségi politikus (Pécs: Karl Könyvesbolt Kiadása, 1927), 21.

4. Domokos Kosáry, trans. Zsuzsa Béres and Christopher Sullivan, Culture and Society in Eighteenth-Century Hungary (Budapest: Corvina, 1987) (reprint), 17, 22.

5. György Szabad, "Hungary's Recognition of Croatia's Self-Determination in 1848 and its Immediate Antecedents," in Béla Király (ed.), East Central European Society and War in the Era of Revolutions: 1775-1856, War and Society in East Central Europe, vol. 4, no. 13 (New York: Columbia University Press, 1984), 599-609; Ambrus Miskolczy, “Társadalmi és nemzeti kérdés az utolsó erdélyi rendi országgyúlésen,” Századok (1979), 851-883.

6. But even during this second period he began to think about the nationality question and to formulate in embryo some of the solutions he would later propose in Szózat.

7. Zsigmond Kemény, "A két Wesselényi Miklós," Báró Kemény Zsigmond munkáiból (Budapest: Franklin Társulat, 1905), 27-29, 43-44.

8. Keith Hitchins, The Rumanian National Movement in Transylvania: 1780-1849 (Cambridge, Mass.: Harvard University Press, 1969), 127-28.

9. Andrew C. János, The Politics of Backwardness in Hungary, 1825-1945 (Princeton, N. J.: Princeton University Press, 1982), 63; György Spira, trans. Zsuzsa Béres, The Nationality Issue in the Hungary of 1848-49 (Budapest: Akadémiai Kiadó, 1992), 13; Professor Spira's estimates on population of Hungary (except from Transylvania) are generally corroborated by estimates of Professor Kosáry. Kosáry, Culture and Society, 17.

10. Spira, 13; See also Hitchins, 9.

11. Robert A. Kann, A History of the Habsburg Monarchy (Berkeley, Cal.: University of California Press, 1974), 174, 199-202.

12. János, 63.

13. Kosáry, Culture and Society, 22.

14. Gyula Szekfü, in introduction to Domokos Kosáry's, A History of Hungary (New York: Arno \& New York Times Press, 1971) (reprint), ix; Spira, 22.

15. Peter E. Sugar, "The Rise of Nationalism in the Habsburg Empire," Austrian History Yearbook, Vol. 3, Pt., (1967), 91-120, 96; Elinor Murray Despalativic, Ljudevit Gaj and the Illyrian Movement, East European Monographs, No. 12 (New York: Columbia, 1975) 13-14; Hitchins, 33-37.

16. Béla Köpeczi (ed.), trans. Adrienne Chambers-Makkai, History of Transylvania (Budapest: Akadémiai Kiadó, 1994), 415.

17. Fónagy, 11-12. His victory, however, was Pyrrhic. Kemény suggested that had the peasant legislation passed, Transylvania might have been spared bloodshed which resulted thirty years 
later. Kemény, 56. Wesselényi publicly admitted his mistake in an 1846 newspaper article. Fónagy, 44-53.

18. George Barany, Stephen Széchenyi and the Awakening of Hungarian Nationalism, 1791-1841 (Princeton, N. J.: Princeton University Press, 1968), 104-105.

19. Kemény, 59-60; István Széchenyi, Gyula Viszota (ed.), Széchenyi István Napló (Budapest: Gondolat, 1978), 238.

20. Fónagy, 12.

21. Trócsányi, 123.

22. Barany, Stephen Széchenyi, 234.

23. Kardos, 1:109-110; Fónagy, 211.

24. Kornél Szentkúti, Müvelődési viszonyok báró Wesselényi Miklós müveiben (Budapest: Grafika Nyomdavállalat, 1937), 89 (citing Gyula Szekfü, Három nemzedék és ami utána következik, 113).

25. Gyula Mérei (ed.), Magyarország története, 1790-1848, 2 Vols., (Budapest: Akadémiai Kiadó, 1983), 2: 669.

26. László Csorba and Ferenc Velkey, Reform és forradalom (1790-1848) (Debrecen: Csokonai Kiadó, 1998), 93, 105-06.

27. István Deák, The Lawful Revolution: Lajos Kossuth and the Hungarians, 1848-49 (New York: Columbia University Press, 1978), 27-28.

28. Mérei, 2: 1266; Barany, Stephen Széchenyi, 313.

29. János Varga, trans. Éva Pálmai, A Hungarian Quo Vadis: Political Trends and Theories of the Early 1840s (In Hungarian Helyét kereső Magyarország: Politikai eszmék és koncepciók az 1840-es évek elején) (Budapest: Akadémiai Kiadó, 1993), 26, 33, 36, 47-48.

30. Miklós Wesselényi, Balitéletekröl. Válogatta, a bevezető tanulmányt írta és a jegyzeteket összeállította Veress Dániel (București: Kriterion Könyvkiadó, 1974), 120-23; Trócsányi, 145-46, citing Wesselényi, Balitéletekröl (original version), 99-101, not all of which was translated in the Romanian-printed excerpts; Lajos Kossuth, Országgyülési tudósitások (reprint), (Budapest: Magyar Történelmi Társulat, 1948), 1: 290-91.

31. Kossuth, 125; Barany, Stephen Széchenyi, 290-91 (much, but not all of Barany's translation of the Sybil speech is used in this quotation); See also Trócsányi, 127.

32. Köpeczi, 467.

33. István Deák, "István Széchenyi, Miklós Wesselényi, Lajos Kossuth and the Problem of Romanian Nationalism," Austrian History Yearbook, 12-13 (1976-77), 69-77, 71; Asztalos, 25.

34. Trócsányi, 127; János, 44; Mérei, 2: 688-9; Veress Introd. Wesselényi, Balitéletekröl, 32-3.

35. Mérei, 2: 688-89.

36. Kossuth, 126-27.

37. Kardos, 1: 406-07.

38. Varga, 26, 36, 47-48; Barany, Stephen Széchenyi, 272.

39. Kossuth, 125; Asztalos, 14; Kardos, 1: 169.

40. Varga, 33.

41. Köpeczi, 464-65.

42. While lifetime military duty had become rare by 1830 , service terms of up to fourteen years were not uncommon. Kann, 239.

43. Kardos, 1: 135-39; Asztalos, 13; and see Kemény, 67.

44. Csorba-Velkey, 107.

45. Kossuth, 126; Kardos, 1: 406-07.

46. Deák, Lawful Revolution, 28.

47. Asztalos, 21; Fónagy, 14.

48. Veress Introduction to Balitéletekröl, 32, 39; Mérei, 1: 688; Asztalos, 22. 
49. The problem is compounded because the most common modern version of the book contains only excerpts from the original work. Quite frequently a secondary source will refer to a passage from Balitéletekröl, yet that passage is not included in the excerpts. In this article, a citation contained in the excerpts will be identified as Balitéletekröl. But where a secondary source refers to a Balitéletekröl reference which is not found in the excerpts, the secondary source will be cited and, if that secondary source cites a page in Balitéletekröl, the notation "Original Balitéletekröl," will also appear.

50. Trócsányi suggests that in 1831, the nationality issue was not as important for Wesselényi as it would become a decade later; and therefore, he gave the ethnic controversy only limited treatment in Balitéletekröl. Trócsányi, 129. See also Asztalos, 25.

51. Fónagy, 85 (citing Original Balitéletekröl, 80); Trócsányi, 145.

52. Wesselényi, Balitéletekröl, 116-17.

53. Wesselényi, Balitéletekröl, 116-17.

54. Varga, 43-44.

55. Asztalos, 24.

56. Mérei, 689 (citing Original Balitéletekröl, 237).

57. Wesselény, Balitéletekröl, 250; Trócsányi, 132.

58. Köpeczi, 462; Wesselényi, Balitéletekröl, 234-36.

59. Wesselényi, Balitéletekröl, 123; Trócsányi, 126-28.

60. Wesselényi, Balitéletekröl, 120-22, 224.

61. Wesselényi, Balitéletekröl, 70-71; Trócsányi, 124-25.

62. Asztalos, 22 (citing Original Balitéletekröl, 57, 282).

63. Wesselényi, Balitéletekröl, 120, 133.

64. Trócsányi, 145-46.

65. Erzsébet Andics, trans. Zoltán Jókai, Metternich und die Frage Ungarns (Budapest: Akadémiai Kiadó, 1973), 70. Metternich told French delegates he only wished to "intimidate, rather than punish" Wesselényi and terrorize Hungary as an object lesson. Barany, Stephen Széchenyi, 344-45.

66. In one speech he reportedly said that the government had sucked the peasants' blood for centuries. In the second, he allegedly asserted that the government had bled white the nation's nine million peasants. C. M. Knatchbull-Hugessen, The Political Evolution of the Hungarian Nation, 2 vols. (New York: Arno Press \& New York Times, 1971) (reprint), 1: 295-96; Mérei, 1:756. The anti-Wesselényi charges may have been defective since he was under political immunity when he spoke. His speeches may have been unwise attacks on both the government and nobility, but may not have been treasonous as he did not criticize the King or advocate overthrow of the Habsburg dynasty. See Asztalos, 16; Barany, Stephen Széchenyi, 301, 347; Szentkúti, 10, 12; Kardos, 1: 191.

67. Széchenyi, Napló, 814-15, 836, 846. April 10, June 20, August 5 and October 18, 1837 entries.

68. Asztalos, 16-17; Deák, Lawful Revolution, 32-33.

69. Miklós Wesselényi, Szózat a magyar és szláv nemzetiség ügyében (Budapest: Európa Könyvkiadó, 1992) (reprint), 17.

70. Trócsányi, 450-51; Asztalos, 17.

71. George Barany, "Hungary: The Uncompromising Compromise," Vol. 3, Pt. 1 Austrian History Yearbook (1967), 240.

72. Varga, 80-82.

73. Varga, 174-76; Francis S. Wagner, "Széchenyi and the Nationality Problem in the Habsburg Empire," Journal of Central European Affairs (1960), 302.

74. Kardos, 2:50; See Wagner, 304-5. 
75. Trócsányi, 452-53; Fónagy, 249.

76. Wesselényi, Szózat, 15; Trócsányi, 453.

77. Wesselényi, Szózat, 17.

78. Wesselényi, Szózat, 19, 21-22; Trócsányi, 453.

79. Wesselényi, Szózat, 19-23.

80. Wesselényi, Szózat, 19, 22-23; Trócsányi, 453-54; Asztalos, 26-27.

81. Wesselényi, Szózat, 29-31.

82. The early twentieth-century Hungarian scholar, Gyula Szekfü described Wesselényi's analysis of the nationality problem as "touchingly naive," and wryly noted that Hungary's late ninth century honfoglalás conquerors would have been acceptable to Wesselényi only had they been endowed with Rousseau-like rationalism. Gyula Szekfü, Három nemzedék és ami utána következik (Budapest: Maecenas, 1983) (reprint), 111-12; See also Varga, 44, 46-47.

83. Deák, "Széchenyi, Wesselényi and Kossuth, 70 (citing Elek Fényes, Magyarország statisztikája, 3 vols. Pest: Trattner Károly tulajdona, 1842-43), Vol. 1, 64, 118.

84. Varga, 151.

85. Wesselényi, Szózat, 87.

86. Wesselényi, Szózat, 199; Trócsányi, 461.

87. Mihály Horváth, trans. Josef Novelli, Fünfundzwanzig Jahre aus der Geschichte Ungarns von 1823-1848, 2 vols. (Leipzig: Brockhaus, 1867), 2: 114-15.

88. Wesselényi, Szózat, 51-54; Trócsányi, 455.

89. Wesselényi, Szózat, 51-55.

90. Wesselényi, Szózat, 33-35; Horváth, 2:114.

91. Endre Arató, A magyarországi nemzetiségek ideológiája (Budapest: Akadémiai Kiadó, 1983), 130-31.

92. Wesselényi does refer to a speech given by Tsar Nicholas I of Russia (who was perhaps not a prime candidate to inspire unity among the Slavic peoples), but otherwise deals in more general assertions. Wesselényi, Szózat, 50-51.

93. Hans Kohn, Pan-Slavism: Its History and Ideology (Notre Dame, Ind.: Notre Dame Press, 1953), 4-5, 99; Despalatovic, 116-17, 119-20.

94. Asztalos, 28-29.

95. Wesselényi, Szózat, 78. See also Dániel Veress, Wesselényi Miklós (Budapest: Móra Ferenc Könyvkiadó, 1983), 162.

96. Wesselényi, Szózat, 77-79, 84-85; Szentkúti, 89.

97. Wesselényi, Szózat, 80-82; Asztalos, 29.

98. Trócsányi, 456.

99. Hitchins, vii-ix; Deák, "Széchenyi, Wesselényi, Kossuth," 74.

100. Hitchins, 169.

101. Wesselényi, Szózat, 151-54, 182-83, 189-90; Horváth, 2: 116.

102. Wesselényi, Szózat, 219-20, 261-62.

103. Wesselényi, Szózat, 46-47; Trócsányi, 455.

104. The five confederative units would include: 1) the German lands (Upper and Lower Austria, Styria, Tirol and Silesia, together with the mixed population of Carinthia and Carniola; 2) the Italian lands (Lombardy, Venetia and Istria); 3) the Czech lands (Bohemia and Moravia); 4) the Polish lands (Galicia and Austrian Lesser Poland); and 5) the Hungarian lands (Central and Northern Hungary, Croatia, Transylvania and Slavonia). Wesselényi, Szózat, 186-89; Knatchbull-Hugessen, 1: 324 (footnote 3); Horváth 2: 116; Trócsányi, 460.

105. Wesselényi, Szózat, 186-88; Trócsányi, 460; Horváth, 2: 116.

106. Wesselényi, Szózat, 189-90. 
107. Horváth, 2:115-16. Wesselényi's confederation idea was destined for stillbirth and had little chance of serious consideration at the time. In a way, the 1867 Compromise, which gave Hungary essential domestic self-rule, might be seen as a hybrid version of Wesselényi's idea. But in 1843, neither Austria nor Hungary showed any enthusiasm for a confederation, although the idea was resurrected by Kossuth nearly twenty-five years later and by Oscar Jászi after the First World War. Oscar Jászi, The Dissolution of the Habsburg Monarchy (Chicago: University of Chicago Press, 1929) (reprint), 313. Nationalism, not confederation was the dominant theme of Wesselényi's age.

108. Varga, 46-47. Trócsányi also argues that the liberals made a serious mistake in believing the nationalities would be satisfied with constitutional rights. Trócsányi, 460-61. Yet assimilation was not without its successes. While largely unsuccessful with the Romanians and Croats, it was quite successful among German and Jewish Hungarians. Perhaps one can better understand the liberals' faith in Magyarization if one considers the large numbers of German and Jewish citizens who adopted their new nation in rather large numbers and often became enthusiastic Hungarian citizens.

109. Trócsányi, 461.

110. Wesselényi, Szózat, 196-97.

111. Wesselényi, Szózat, 204; Szentkúti, 90.

112. Wesselényi, Szózat, 107-08; Barany, "Uncompromising Compromise,” 236; Asztalos, 30.

113. Asztalos, 18 .

114. Benedek, 237-38.

115. Deák, Lawful Revolution, 125-27, 220.

116. Trócsányi, 528-9; Asztalos, 18.

117. Szabad, 600; Alan Sked, The Decline and Fall of the Habsburg Empire 1815-1918 (New York: Longman, 1989) $8^{\text {th }}$ ed. 96.

118. Köpeczi, 498.

119. Miskolczy, 877.

120. Köpeczi, 498, Miskolczy, 877.

121. Miskolczy, 877-78.

122. Köpeczi, 498.

123. Köpeczi, 498 (citing Miskolczy, 878).

124. Miskolczy, 878.

125. Trócsányi, 545-46. Wesselényi's nationality bill provided that: 1) all of Transylvania's Christians, whether Orthodox or related faiths, would be entitled to equal religious treatment; 2) vital statistics kept by religious authorities could be filed in either the Hungarian or Romanian languages; 3) primary school instruction could be in either Romanian or Hungarian; 4) official records which were filed with a notary could be written in either Romanian or Hungarian; 5) documents written in Romanian could be filed in any government office provided those documents were written in Latin, as opposed to Cyrillic, letters. Fónagy, 87-88; Trócsányi, 546.

126. Asztalos, 20.

127. Trócsányi, 546.

128. Fónagy, 20.

129. Kemény, 62.

130. Sugar, "Rise of Nationalism," 91, 110, 120.

131. Imre Madách, trans. Thomas R. Mark, The Tragedy of Man (New York: Columbia University Press, 1989), scene XIII, 121.

132. Elementary Education and Nationality Acts of 1868.

133. Article 68: (1) The national and ethnic minorities living in the Republic of Hungary share the 
power of the people; they are constituent factors in the state; (2) The Republic of Hungary grants protection to national and ethnic minorities, it insures the possibilities for their collective participation in public life and enables them to foster their own culture, use the mother tongue, receive school instruction in the mother tongue and freedom to use their names as spelled and pronounced in their own languages. 